\title{
Taylor's Conception of the Laws of War
}

\section{Marshall Cohen $\dagger$}

Nuremberg and Vietnam: An American Tragedy. By Telford Taylor. Chicago: Quadrangle Books, 1970. Pp. 224. $\$ 5.95$ (clothbound), $\$ 1.95$ (paperback).

Taylor finds certain persistent inadequacies in the laws of war and in the crucial concept of military necessity. He believes, nevertheless, that the laws of war and the principle of military necessity serve an important purpose and that they ought to be preserved and enforced. I am far from certain that I understand the nature of all the inadequacies Taylor finds in the laws of war. But there can be no doubt that there are such inadequacies-some of the sort Taylor mentions and others of a more ethical nature. I agree with Taylor that despite these difficulties the laws of war are worth preserving and refining. But his failure to address the moral difficulties that $I$ have in mind weakens, and may in fact undermine, the main argument he offers for thinking that this branch of law makes an important contribution to preserving civilized values.

Taylor illustrates the crucial "dilemma,"1 the central "ambiguity" that he finds in the laws of war by comparing two passages from the Army's field manuals, one from the 1917, the other from the 1956, version. According to the 1917 version the laws of war are determined by the following principles:

First, that a belligerent is justified in applying any amount and any kind of force which is necessary for the purpose of the war; that is, the complete submission of the enemy at the earliest possible moment with the least expenditure of men and money. Second, the principle of humanity, which says that all such kinds and degrees of violence as are not necessary for the purpose of war are not permitted to a belligerent. ${ }^{3}$

$\dagger$ Professor of Philosophy, City University of New York, and Editor of Philosophy and Public Afairs. B.A. 1951, Dartmouth College; M.A. 1953, Harvard University.

1. T. TAYzor, Nurearberg and Vietnam: An American Tragedy 38 (1970) [hercinafter cited to page number only].

2. P. 35.

3. U.S. DEP'T OF WAR, RuLES of LAND WARFARE, para. 9 (1917) (War Dep't Doc. No. 467. Office of the Chief of Staff, approved April 25, 1914) (emphasis in original), quoted at p. 34. The 1917 version also lists a rather vaguely worded "principle of chivalry," which $I$ have not quoted, as a principle of the laws of war. 
This, according to Taylor, "is a plain statement of the rule of military necessity; if the use of force is necessary, it is lawful, and if unnecessary, it is unlawful." $=$ It should be observed that, so defined, the principle of humanity places no limitation on the principle of military necessity, since the former is concerned only with violence which is "not necessary." Given these definitions, it is erroneous to speak of the laws of war as a compromise between the principle of military necessity and the principle of humanity; for, so conceived, these principles cannot come into conflict. To speak as though the laws of war are the result of a compromise between them must mean that there are military interests more ambitious than those justified by the principle of military necessity, and humane interests more comprehensive than those guaranteed by the principle of humanity, and that it is these interests which are compromised. At the level of principle, however, no further compromise is effected. Thus, on this conception of the laws of war, a plea of military necessity is always legitimate since there is no competing principle forceful enough to rule it out.

If the 1917 passage is plain, the "great," as yet unresolved, "dilemma" that Taylor finds in the rules of war is reflected in an "ambiguity" that he detects in the 1956 statement. I give part of Taylor's quotation:

The prohibitory effect of the law of war is not minimized by "military necessity" which has been defined as that principle which justifies those measures not forbidden by international law which are indispensible for securing the complete submission of the enemy as soon as possible. Military necessity has been generally rejected as a defense for acts forbidden by the customary and conventional laws of war inasmuch as the latter have been developed and framed with consideration for the concept of military necessity. ${ }^{\circ}$

It is, of course, possible to find a verbal ambiguity here. For, when the passage states that the laws of war have been framed with consideration for "the concept of military necessity," it must mean with consideration for the military interest (or possibly, with consideration for the principle of military necessity). But, when it says that "military necessity" had been "defined as that principle which justifies those measures not forbidden by international law which are indispensible

4. P. 34.

5. Pp. 33, 35.

6. U.S. Dep'T OF ARaY, The LAW OF LANo Warfare, para. 3 (1950) (Dep't of Ammy Field Manual FM 27-10), quoted at pp. 34-35. 
for the complete submission of the enemy as soon as possible," it is referring to neither of them. Rather, it is invoking what may be called the Lieber-Hague (henceforth the Hague) conception of the laws of war. ${ }^{8}$ This conception permits the interests of humanity to carry enough weight so that they can sometimes inhibit the operation of the principle of military necessity. On this conception, therefore, the plea of military necessity is by no means always a legitimate one; indeed, it is sometimes plainly ruled out. Certainly, then, it is at least misleading to characterize the very conception that results in restrictions on the principle of military necessity by the term "military necessity" itself. But, confusing as this may be, there is nothing essentially ambiguous about the passage which Taylor quotes. The verbal ambiguity in no way weakens the impact of the 1956 passage, which, as I read it, unequivocally endorses the Hague conception of the rules of war. What really bothers Taylor is not, I think, the putative ambiguity of the passage but his doubt that any restrictions of the sort the Hague conception places on the principle of military necessity can in fact survive as valid law given the changing conditions of war, the vagueness of the conception of "military necessity," and the very imperiousness of necessity's demands.

So, immediately after his discussion of the ambiguity of the 1956 passage, Taylor proposes to illustrate the dilemmas and difficulties inherent in the laws of war by offering some "pragmatic" examples. They will show, he says, that "necessity" is a matter of "infinite circumstantial variation,"10 and later he extracts the "lesson of all these examples, which is that the laws of war do not have a fixed content, but are constantly reshaped by the exigencies of warfare." 11 But, in fact, the difficulties that Taylor alleges do not invalidate a Hague conception of the laws of war nor show that they cannot resist the pressures of military necessity. For, whatever may be meant by saying that the con.

7. Id. (emphasis added).

8. According to Taylor, in "the Lieber rules of 1863 , military necessity was defned as 'those measures which are indispensable for securing the ends of war, and which are lawful according to the modern law and usages of war'." P. 33 (emphasis added). Hencc, under the Lieber doctrine, an action had to be both indispensable to the ends of the war and otherwise permitted by the laws of war to be covered by the principle of milltary necessity. The scope of that principle is also testricted by the Hague Convention of 1907, under which it is "especially forbidden" to "kill or wound an enemy who, having laid down his arms, or having no longer means of self-defense, has surrenderced at discretion." That Convention also forbade a declaration "that no quarter will be given." (Quoted at $\mathrm{p}$. 35.) If such acts are forbidden without qualification, no principle of military necessity can endow them with a permissible character which they have otherwise been stated to lack.

9. P. 35.

10. id.

11. P. 38. 
cept of military necessity is capable of "infinite circumstantial variation," all that is required to sustain a Haguedike conception of the rules of war is that in certain of these circumstances the claims of military necessity should be denied. Now it sometimes appears that what bothers Taylor is not so much the variety or instability of military circumstances as it is the vagueness of the concept of military necessity itself. But the concept of military necessity is much like the concepts of due process and fair price; commanders are as capable of taking guidance from the rules employing this concept as courts are of applying similarly vague judicial concepts. Often enough the killing of survivors, the torture of prisoners, and the plunder of captured cities are not justified, and are not thought to be justified, by the principle of military necessity. In any case, even if the concept is vague, its vagueness is less damaging to a Hague conception whose rules do not always permit its invocation than it is to a "plainer," more "realistic" conception of the laws of war that can never avoid it.

In the end, Taylor relies on the simple fact that rules which attempt to restrict the operation of the principle of necessity are ineffective. But, in addition to the fact that he moves too easily from the alleged ineffectiveness of rules to their lack of validity, ${ }^{12}$ Taylor's own examples are not persuasive here. Often when he claims that the courts have acceded to demands of military necessity, it is far from clear that they have done so; and even if they had done so in the specific cases he mentions, this is far from showing that they do so whenever the demands arise. Indeed, the International Military Tribunal was notable for the firmness with which it rejected pleas of military necessity. ${ }^{13}$ Besides, as we shall see, Taylor's own "realism" in this matter, if consistently pursued, would take him farther in the direction of legalizing crime than I think he would care to go. Before pursuing that issue, however, let us confirm these observations by considering Taylor's own examples.

A crucial rule of war requires that an enemy soldier who surrenders is to be spared further attack, and, upon being taken prisoner, is to be conducted as soon as possible to safety in the rear of the capturing

12. On the distinction between validity and efficacy, see, e.g., H.L.A. HAst, ThE CoNCEPT OF LAW 100-01 (1961). Nothing Hart says suggests that this distinction cannot be applied in the area of international law. One might, of course, argue that in international law efficacy is in fact the criterion of validity. But, if I have interpreted Taylor correctly (see pp. 1499.1500 infra), he cannot tely on such a view. In any case, I should reject it.

13. See, e.g., United States v. Litt, reported in 11 Truts of WAR Crusmals 1280, 1255-56, 1272 (1950) "The Hostage Case"). See generally, M. MCDovoat \& E, Feliculio, LAW AND MINIAUUA WORLS PUELIC ORDER 676.78 (1961). 
force. But, Taylor points out, in certain circumstances this rule is violated. ${ }^{14}$ Sometimes in the heat of battle prisoners are killed even though they might have been taken prisoner-a circumstance which, of course, shows nothing about the validity of the rule. Sometimes, too, they are killed in cold blood on the orders of "humane" commanders when "[s]mall detachments on special missions, or accidentally cut off from their main force, . . . take prisoners under such circumstances that men cannot be spared to guard them or take them to the rear, and that to take them along would greatly endanger the success of the mission or the safety of the unit." 15 Taylor says that these prisoners will be killed in accordance with the principle of military necessity and that no military court has been called upon, so far as he is aware, to declare such killing a war crime.

To begin with, the vulnerable position of a small squad cut off from its main force has all the makings of a special case, and would not show that in more typical cases prisoners will or should be sacrificed if doing so will lead to what the principle of military necessity describes as "the complete submission of the enemy at the earliest possible moment with the least expenditure of men and money."10 But even in the special case, commentators are virtually unanimous in maintaining that when such killings are undertaken to guarantee the success of a mission they violate the laws of war. ${ }^{17}$ Moreover, it is far from clear what follows from the fact, if it is a fact, that no court has been called upon to declare such killings criminal. It surely does not follow that they are not criminal. Where the killing of prisoners has been undertaken not to secure the success of a mission-the case most favorable to Taylor's view-but to secure the safety of the unit itself there has, to be sure, been controversy about the proper rule. Some have suggested that the requirement is absolute and that, after being disarmed, the prisoners should be freed; ${ }^{18}$ others have argued that under certain circumstances they may, in fact, be killed. ${ }^{19}$ But, and this is crucial, even those who say that the prisoners may be killed are not necessarily relying on the principle of military necessity. A much narrower principle of self-de-

14. P. 36.

15. Id.

16. See p. 1492 supra.

17. See, e.g., M. Greenspan, The Modern Law of LANd Warfare 103 (1959); 2 L. OPPENHEIM, INTERNATIONAL LAW 339 n.3 (7th ed. H. Lauterpacht 1948).

18. See, e.g., W. HALI, INTERNATIONAL LAW 474 (8th ed. A. Higgins 1924); Aluéfuc ROLIN, LE DROIT MODERNE DE LA GUERRE 286-88 (1920); 2 H. WHEATON, INTERNATIONAL LAw 179-80 (7th ed. A. Keith 1944).

19. J. BLUNTSChLI, DAs MODERNE VölKerRecht der Civilisirten STATEN § 580 (1878); 8

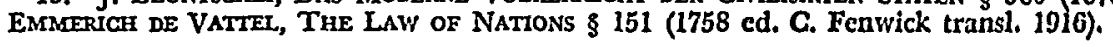


fense, or self-preservation, will suffice. If this narrower principle is also described as the "principle of military necessity," an ambiguity has indeed been introduced and this time it is a crucial and even vicious one.

Similar objections apply to Taylor's other major example, drawn from the development of naval warfare. The London Naval Treaty of 1930 forbids warships from sinking merchant vessels "without having first placed passengers, crew, and ship's papers in a place of safety." Soon after the outbreak of the Second World War, however, it became apparent that due to the development of "[r]adar, sonar, convoys and long-range aircraft" it was "virtual suicide" for a submarine "to surface anywhere near its target, let alone to remain in the vicinity for rescue operations." ${ }^{21}$ These rescue provisions were, as a result, generally ignored. When Admirals Raeder and Doenitz were charged with violating the London Treaty, Admiral Nimitz testified that in respect to the rescue provisions the Germans had done nothing that the British and Americans had not also done. Taylor observes that " $[t]$ he Nuremberg Tribunal therefore ruled that, while Raeder and Doenitz had indeed violated the London rescue stipulations, they would not be subjected to any criminal penalties on that account. The plain rationale of this decision was that the London rescue requirements were no longer an effective part of the laws of naval warfare, because they had been abrogated by the practice of the belligerents on both sides under the stress of military necessity." $2 \mathrm{n}$ He also observes that the scope of application of the laws of war must be limited by the extent to which they had been observed by the enforcing party. "To punish the foe-especially the vanquished foe-for conduct in which the enforcing nation has engaged, would be so grossly inequitable as to discredit the laws of war themselves." ${ }^{23}$

In fact, however, the Tribunal was far from relaxing the requirement. It said that "[i]f the Commander cannot rescue, then under the [terms of the international law] he cannot sink a merchant vessel and should allow it to pass unharmed before his periscope."2t Certainly, then, the Tribunal did not take the practice of belligerents to undermine the validity of the rule. All it said was that in consequence of the breach on both sides "the sentence of Doenitz is not assessed." 25 The

20. Quoted at p. 37 .

21. P. 37 .

22. P. $37-38$.

23. P. 89.

24. 22 The Trial of Gerasan Major War Criminals 509 (H.A1.S.O. 1950).

25. Id. 
Tribunal appears to have invoked a doctrine of estoppel, and its reliance on this doctrine does not entail that the rule is no longer valid law. The Tribunal did not acquiesce in the principle of military necessity, but plainly upheld the validity of a rule that was meant to limit the force of that principle. ${ }^{28}$

The examples examined above do not show that the laws of war cannot or, indeed, that they do not, restrict the principle of military necessity. But Taylor's discussion of the aerial bombardment of civilian populations suggests that, given his own line of reasoning, the laws of war are not subject even to the limits imposed by the principle of military necessity. Thus, in one passage Taylor remarks that there was "not much law left" ${ }^{\prime 27}$ governing the bombardment of civilian populations at the end of World War II. He claims, in consequence, that there was "no basis for criminal charges against Germans and Japanese"28 after World War II and that there is no basis for such charges in connection with our own bombings in North Vietnam today. ${ }^{2 \theta}$ On the other hand, he believes that the bombings of Dresden and Nagasali were, in fact, criminal, as he believes that some of our own bombing practices in South Vietnam are today. (The bombing of Hiroshima can, he thinks, perhaps be justified, ${ }^{30}$ although the Shimoda court, which did not agree that there was "not much law left" at the end of World War II, judged it in violation of international law. ${ }^{31}$ Now, if Taylor believes that the Germans and the Japanese engaged in bombing practices comparable to those in which the Allies at Dresden and Nagasaki engaged, he ought not to say (whether because the rules against such bombing were no longer effective, because customary practice had changed, or because practices that both sides engage in cannot be illegal) that the bombing of Dresden and Nagasaki was criminal. Furthermore, since he apparently believes that the bombing of Dresden and Nagasaki violated the "proportionality" requirement implicit in the principle of

26. Of course, it could be argued that the rule should be applied to victor and vanquished alike. In any case, invoking this doctrine does not preclude applying the rulc to other parties or in other circumstances. The point being made in the text is simply that there is no inconsistency in the Tribunal's invoking this doctrine and still professlng' the validity of the rule.

27. P. 140 .

28. P. 141 .

29. P. 142 .

30. P. 143 .

31. I refer here to Shimoda v. Japan, 355 Hanrei Jiho 17 (Tokyo Dist. Ct. Dec. 7, 1963), in which a Japanese civil court, while denying damages to survivors of Hiroshima and Nagasaki, characterized the bombings as "contrary to the fundamental principles of the laws of war." The case is mentioned by Taylor at p. 141 n.12. It is discussed

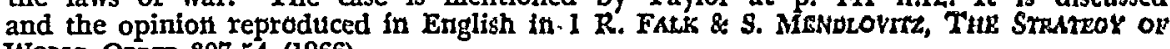
WORLD ORDER 307-54 (1966). 
military necessity, ${ }^{32}$ he ought to conclude, if efficacy is the criterion of validity, that at the end of World War II the laws of war no longer imposed even a requirement of military necessity. Unfortunately, Taylor does not speak to the issue of German and Japanese practice regarding proportionality in aerial warfare and follows his observations about Dresden and Nagasaki with the morally pertinent but legally unhelpful observation that they are "tolerable in retrospect only because their malignancy pales in comparison to Dachau, Auschwitz and Treblinka." 33 He does try to avoid the consequence that even the principle of military necessity was invalidated at the end of World War II by saying that " $[\mathrm{t}] \mathrm{o}$ a degree" 34 the proportionality principle was observed in World War II-Oxford and Heidelberg were not bombed. But the crucial point would seem to be that London, Coventry and Rotterdam were. Taylor attempts to salvage the vitality of the principle of military necessity by making it an article of faith that violations of that principle are illegal. Were he to continue applying his dubious principles about effectiveness, current practice, and reciprocity, he would have to conclude that the principle of military necessity was inefficacious and so invalid at the end of the Second World War.

But if he is willing to ignore, or to subordinate, these arguments when they jeopardize the validity of the principle of military necessity, why does he not do so at a point more favorably disposed to the interests of humanity? If he waived them at a different point, he could give more weight to the principle of humanity. This would not only permit Taylor to give a more accurate account of the laws of war (reflecting the Hague conception which underlies many of them), but would also strengthen his own arguments in favor of preserving and enforcing these laws. Indeed, Taylor's own arguments in this matter are weakened, and perhaps even undermined, by his failure to give sufficient weight to the prohibition on the deliberate killing of innocent persons. Taylor argues that the laws of war are valuable because they save lives. But this is not a wholly satisfactory argument. If the laws of war saved guilty lives at the expense of innocent ones, or belligerent lives at the expense of pacific ones, their value would be dubious or worse. And if the existence of the laws of war encouraged men to think that the bombing of Hiroshima was acceptable because they thought it legal,

34. Id. 
then the laws of war may have augmented the loss of lives-and the loss of the wrong ones at that. However that may be, the importance of the prohibition on the killing of innocents creates still greater problems for what Taylor takes to be the most important argument for preserving the laws of war, namely, that they diminish the corrosive effect of mortal combat on the participants. Thus he writes that "[u]nless troops are trained and required to draw the distinction between military and nonmilitary killings, and to retain such respect for the value of life that unnecessary death and destruction will continue to repel them, they may lose the sense for that distinction for the rest of their lives." ${ }^{\text {ss }}$ The consequence would be that many returning soldiers would be potential murderers. Surely, however, the distinction between military and nonmilitary killings is substantially irrelevant to civilian life. A distinction between necessary and unnecessary killings is, to be sure, sometimes invoked in civilian life. For example, a homicide which would otherwise be criminal or immoral may be neither if a person is attacked and finds it necessary to kill his assailant in order to preserve his own life. But this is not the distinction that a soldier learns when he learns the distinction between killing that is necessary from a military point of view and that which is not. And that distinction, like the distinction between military and nonmilitary killing, is irrelevant to civilian life. Taylor's argument will have to be, then, that the value of the laws of war is that they teach soldiers the distinction between legitimate and illegitimate killings. No doubt this will be of value to those-presumably there will not be very many-who would return to civilian life having forgotten that there is one. Unfortunately, however, given the laws of war as Taylor understands them, ex-soldiers will have learned that the deliberate killing of innocent persons may be "necessary," and even legally permissible in many circumstances that moral principle would condemn. Learning this lesson about what may be legitimate, if it has any effect at all, can only increase the chances that these men will be potential murderers-and legalizers of murder. There is no safety here.

The principles of morality are not one among a number of com. peting interests. They are the principles that must govern the pursuit of all interests. Unless the laws of war reflect these principles more closely than Taylor thinks they do, the laws of war will gain little support from the kind of defense he offers. Fortunately, that defense is less crucial, and more substantial, than Taylor's argument suggests.

35. P. 41 . 